\title{
Unresectable Malignant Digestive System Neoplasm
}

National Cancer Institute

\section{Source}

National Cancer Institute. Unresectable Malignant Digestive System Neoplasm. NCI

Thesaurus. Code C162845.

A malignant digestive system neoplasm that is not amenable to surgical resection. 